\title{
Water Reuse: Emerging Contaminants Elimination-Progress and Trends
}

\author{
Djamel Ghernaout ${ }^{1,2 *}$, Noureddine Elboughdiri1,3 \\ ${ }^{1}$ Chemical Engineering Department, College of Engineering, University of Ha'il, Ha'il, KSA \\ ${ }^{2}$ Chemical Engineering Department, Faculty of Engineering, University of Blida, Blida, Algeria \\ ${ }^{3}$ Département de Génie Chimique de Procédés, Laboratoire Modélisation, Analyse, et Commande des systèmes, Ecole Nationale \\ d'Ingénieurs de Gabès (ENIG), Gabès, Tunisia \\ Email: ^djamel_andalus@hotmail.com
}

How to cite this paper: Ghernaout, D. and Elboughdiri, N. (2019) Water Reuse: Emerging Contaminants Elimination-Progress and Trends. Open Access Library Journal, 6: e5981.

https://doi.org/10.4236/oalib.1105981

Received: December 9, 2019

Accepted: December 24, 2019

Published: December 27, 2019

Copyright $\odot 2019$ by author(s) and Open Access Library Inc.

This work is licensed under the Creative Commons Attribution International License (CC BY 4.0).

http://creativecommons.org/licenses/by/4.0/

\section{(c) (i) Open Access}

\begin{abstract}
This work concentrates on the review paper published by Ahmed et al. [1] which is dedicated to the elimination of emerging contaminants (ECs) using biological, chemical and hybrid techniques in effluents from wastewater treatment plants (WWTPs). Endocrine disruption chemicals (EDCs) are better reduced by a membrane bioreactor (MBR), activated sludge, and aeration processes between various biological processes. Surfactants, EDCs and personal care products (PCPs) may be well reduced using activated sludge processes. Pesticides and pharmaceuticals manifested convenient reduction performances by biological activated carbon. Microalgae treatment techniques may diminish nearly all sorts of ECs to a certain degree. Additional biological methods were observed less efficient in dealing with ECs. Chemical oxidation techniques (like ozonation $/ \mathrm{H}_{2} \mathrm{O}_{2}$, UV photolysis $/ \mathrm{H}_{2} \mathrm{O}_{2}$, and photo-Fenton) may greatly eliminate up to $100 \%$ of pesticides, beta-blockers, and pharmaceuticals; at the same time, EDCs may be better reduced via ozonation and UV photocatalysis. Fenton method was observed less efficient in treating any sorts of ECs. A merged setup founded on ozonation pursued by biological activated carbon was manifested hugely efficacious in eliminating pesticides, beta-blockers, and pharmaceuticals. An integrated ozonation-ultrasound device may eliminate until $100 \%$ of numerous pharmaceuticals. Next research orientations to boost the elimination of ECs have been suggested.
\end{abstract}

\section{Subject Areas}

Environmental Sciences

\section{Keywords}

Water Reuse, Emerging Contaminants (ECs), Endocrine Disruption Chemicals 
(EDCs), Membrane Processes, Wastewater Treatment, Advanced Oxidation Processes (AOPs)

\section{Introduction}

Emerging contaminants (ECs) are mainly synthetic organic chemicals that have been lately found in natural mediums [1] [2] [3] [4] [5]. ECs are a huge and comparatively novel group of unregulated complexes [6] and may easily induce harmful influences in aquatic and human life at naturally pertinent levels, which are beginning an increasing worry [2] [7] [8]. They are the components predominately found in urban sewage, daily household products, pharmaceutical production facilities, wastewater, hospitals, landfills, and natural aquatic mediums [9] [10] [11]. ECs levels may extend from a few $\mathrm{ng} / \mathrm{L}$ to a few hundred $\mu \mathrm{g} / \mathrm{L}$ [10] [12]. Such levels in the aquatic medium may produce ecological hazards like interference with the endocrine system of high organisms, microbiological resistance, and accumulation in soil, plants, and animals [13], because such ECs are not totally eliminated throughout traditional wastewater treatment techniques [8] [14] [15]. ECs comprise mainly pharmaceutical organic pollutants, personal care products (PCPs), endocrine disrupting compounds (EDCs), surfactants, pesticides, flame-retardants, and industrial additives among others [1].

Pharmaceutical organic contaminants and PCPs contain analgesics, lipid regulators, antibiotics, diuretics, non-steroid anti-inflammatory drugs, stimulant drugs, antiseptics, analgesics, beta-blockers, antimicrobials, cosmetics, sunscreen agents, food supplements, fragrances, and their metabolites and transformation products [1]. They may touch water quality and greatly influence potable water supplies, ecosystem and human health [15] [16] [17]. Their environmental bioaccumulation worsens the abnormal hormonal control inducing reproductive impairments, diminished fecundity, augmented incidence of breast and testosterone cancers, and persistent antibiotic resistance [18]. More important, antibiotic residues may cause the development of antibiotic-resistant genes hugely favoring superbugs [8].

EDCs are exogenous substances or mixtures that modify the roles of the endocrine systems and then induce negative health influences in an intact organism, or its progeny or populations [19]. The impacts linked to EDCs are breakage of eggs of birds, fishes, and turtles, problems in reproductive systems, alteration in the immunologic system of marine mammals, a decrease of sperm of human organ, elevation in the incidence of breast, testicle and prostate cancers, and endometriosis [16]. Pesticides have immune-depressive impacts in fishes, mammals and may alter hemopoietic tissue of anterior kidney [20]. Surfactants can touch the physical stability of human growth hormone formulations and are responsible for the endocrine activity [1] [21]. 
A set of diverse physical, chemical, and biological techniques have previously been utilized to eliminate or decompose the remains of ECs during the past years [22] [23]. Biological treatment techniques remain the most largely employed for eliminating ECs, comprising activated sludge, constructed wetland, membrane bioreactor (MBR), aerobic bioreactor, anaerobic bioreactor, microalgae bioreactor [24] [25], fungal bioreactor, trickling filter, rotating biological reactor, nitrification, enzyme treatment, and biosorption. Several non-biodegradable organic micropollutants cannot be enough reduced employing biological treatment techniques [5] [26] [27]. Chemical treatment processes are also largely employed for decomposing such micropollutants [26] [27], involving traditional oxidation techniques like Fenton, ozonation, photolysis, and advanced oxidation processes (AOPs) [28] [29] like ferrate [30] [31] [32], photo-Fenton, photocatalysis, solar-driven processes, ultrasound process, and electro-Fenton method. Furthermore, numerous hybrid systems have newly been implemented to improve the elimination of a large span of ECS. Table 1 lists the benefits and dares of diverse methods for eliminating ECs [1].

The plurality of polar and semi-polar pesticides and pharmaceuticals will stay partitioned in the aqueous phase because of their comparatively elevated water solubility; for this reason, their reduction via physical processes like sedimentation and flocculation is not efficient [67] as it has been mentioned to be less than $10 \%$ [68] [69]. As a result, additional debates of those methods are not revised here. The debate of extra physical treatment techniques like membrane [70], reverse osmosis (RO), ultrafiltration (UF), microfiltration (MF), NF, and adsorption methods is also kept out from this work, even if such physical approaches can be a piece of hybrid or integrated treatment techniques for eliminating ECs [1] [71].

Therefore, this work aims to deeply assess the viability of biological, chemical, and hybrid treatment processes as a tool to eliminate ECs from wastewater. Particularly, the paper presents an outline of the efficacy of diverse wastewater treatment techniques for eliminating ECs. It also estimates traditional wastewater treatment methods along with amelioration and hybrid treatment techniques for reducing ECs. It also assesses the dares and the actual comprehension inabilities restricting the performance of biological and chemical treatment technologies. Several of the future research trends are as well proposed.

\section{Biological Treatment Techniques}

Biological treatment techniques have been largely used for eliminating ECs mostly via the pathway of biodegradation. Biodegradation is the method during which large molecular weight ECs are decomposed by microorganisms like bacteria [72] [73] [74] [75], algae [76] [77], and fungi into small molecules [6], and even biomineralized to simple inorganic molecules like water and carbon dioxide. During the traditional biodegradation method, microorganisms employ organic complexes as first substrates for their cell development and induce 
Table 1. Benefits and dares of diverse techniques in eliminating ECs [1].

\begin{tabular}{|c|c|c|}
\hline Treatment method & Benefits & Dares \\
\hline $\begin{array}{l}\text { Traditional } \\
\text { Biological activated } \\
\text { carbon }\end{array}$ & $\begin{array}{l}\text { A large variety of ECs reduction from wastewater. } \\
\text { Reduction of remaining disinfection/oxidation } \\
\text { products [33] [34] [35] [36]. } \\
\text { Not producing hazardous active products. }\end{array}$ & $\begin{array}{l}\text { Comparatively elevated cost in running and maintenance. } \\
\text { Regeneration and disposal hurdles of high sludge. } \\
\text { Processing of sludge may elevate global cost by } 50 \%-60 \% \text {. }\end{array}$ \\
\hline Microalgae reactor & $\begin{array}{l}\text { Resource recovery of algal biomass, employed as } \\
\text { fertilizer [37] [38] [39]. } \\
\text { Elevated quality effluent \& no acute toxicity danger } \\
\text { linked with ECs. }\end{array}$ & $\begin{array}{l}\text { Reduction efficiencies touched by cold season. } \\
\text { EDCs cannot be decomposed conveniently. }\end{array}$ \\
\hline Activated sludge & $\begin{array}{l}\text { Lower capital and operational costs than AOPs. } \\
\text { More environmental friendly than chlorination [40] } \\
{[41][42] \text {. }}\end{array}$ & $\begin{array}{l}\text { Low efficiencies for pharmaceuticals and beta-blockers. } \\
\text { Large amount of sludge containing ECs. } \\
\text { Unsuitable where chemical oxygen demand levels are greater than } \\
4000 \mathrm{mg} / \mathrm{L} \text {. }\end{array}$ \\
\hline $\begin{array}{l}\text { Non-traditional } \\
\text { Constructed wetland }\end{array}$ & $\begin{array}{l}\text { Low energy consumption and low operational \& } \\
\text { maintenance costs. } \\
\text { High performance on removal of estrogens, PCPs, } \\
\text { pesticides and pathogens. }\end{array}$ & $\begin{array}{l}\text { Clogging, solids entrapment and sediments formation. } \\
\text { Biofilm growth, chemical precipitation and seasonal dependent. } \\
\text { Needs large area of lands and long retention time. }\end{array}$ \\
\hline MBR & $\begin{array}{l}\text { Effective for the removal of bio-recalcitrant and ECs. } \\
\text { Small footprint. }\end{array}$ & $\begin{array}{l}\text { High-energy consumption, fouling, and control of heat and mass } \\
\text { transfer. } \\
\text { High aeration [43] cost and roughness of membrane [44] [45]. } \\
\text { Pharmaceutical pollutants have low efficiencies. }\end{array}$ \\
\hline $\begin{array}{l}\text { Chemical process } \\
\text { Coagulation }\end{array}$ & $\begin{array}{l}\text { Reduced turbidity arising from suspended inorganic } \\
\text { and organic particles [46] [47] [48]. } \\
\text { Increased sedimentation rate through suspended } \\
\text { solid particles formation [49] [50] [51]. }\end{array}$ & $\begin{array}{l}\text { Ineffective micropollutants removal [52] [53] [54]. } \\
\text { Large amount of sludge [55] [56] [57]. } \\
\text { Introduction of coagulant slats in the aqueous phase [58] [59] [60] } \\
{[61] .}\end{array}$ \\
\hline Ozonation & $\begin{array}{l}\text { Strong affinity to ECs in the presence of } \mathrm{H}_{2} \mathrm{O}_{2} \text {. } \\
\text { Selective oxidant favoring disinfection and } \\
\text { sterilization properties [62]. }\end{array}$ & Interference of radical scavengers. \\
\hline AOPs & $\begin{array}{l}\text { Major ancillary effects on removal of ECs such as } \\
\text { EDCs, pharmaceuticals, PCPs and pesticides. } \\
\text { Short degradation rate. }\end{array}$ & $\begin{array}{l}\text { Energy consumption issues, operational \& maintenance cost. } \\
\text { Formation of toxic disinfection by-products [63] [64]. } \\
\text { Interference of radical scavengers. }\end{array}$ \\
\hline $\begin{array}{l}\text { Fenton and } \\
\text { photo-Fenton }\end{array}$ & $\begin{array}{l}\text { Degradation and mineralization of ECs. } \\
\text { Sunlight can be used by avoiding UV light. }\end{array}$ & $\begin{array}{l}\text { Decrease of }{ }^{\bullet} \mathrm{OH} \text { forming chloro and sulfato- } \mathrm{Fe}(\mathrm{III}) \text { complexes or } \\
\text { due to scavenge of }{ }^{\bullet} \mathrm{OH} \text { forming } \mathrm{Cl}_{2}{ }^{\bullet} \text { and } \mathrm{SO}_{4}{ }^{\bullet-} \text { in the presence of } \\
\text { chloride and sulfate ions. }\end{array}$ \\
\hline Photocatalysis $\left(\mathrm{TiO}_{2}\right)$ & $\begin{array}{l}\text { Degrading persistent organic compounds. } \\
\text { High reaction rates upon using catalyst. } \\
\text { Low price and chemical stability of } \mathrm{TiO}_{2} \text { catalyst and } \\
\text { easier recovery. }\end{array}$ & $\begin{array}{l}\text { Difficult to treat large volume of wastewater. } \\
\text { Cost associated with artificial UV lamps and electricity. } \\
\text { Separation and reuse of photocatalytic particles from slurry } \\
\text { suspension. }\end{array}$ \\
\hline $\begin{array}{l}\text { Physical process } \\
\text { Micro-orultra-filtration }\end{array}$ & $\begin{array}{l}\text { Can remove pathogens. } \\
\text { Applicable for heavy metal removal. }\end{array}$ & $\begin{array}{l}\text { Not fully effective in removing some ECs as pore sizes vary from } \\
100 \text { to } 1000 \text { times larger than the micropollutants. } \\
\text { High cost of operation. }\end{array}$ \\
\hline Nanofiltration (NF) & $\begin{array}{l}\text { Useful for treating saline water and wastewater } \\
\text { treatment plants (WWTPs) influents. } \\
\text { Can remove dyestuff and pesticides. }\end{array}$ & $\begin{array}{l}\text { High-energy demand, membrane fouling and disposal issue [65]. } \\
\text { Limited application in pharmaceutical removal. }\end{array}$ \\
\hline Reverse osmosis & $\begin{array}{l}\text { Useful for treating saline water and WWTP } \\
\text { influents. } \\
\text { Can remove PCPs, EDCs and pharmaceuticals. }\end{array}$ & $\begin{array}{l}\text { High-energy demand, membrane fouling and disposal issue [66]. } \\
\text { Corrosive nature of finished water \& lower pharmaceutical } \\
\text { removal. }\end{array}$ \\
\hline
\end{tabular}


enzymes for their ingestion [12] [78] [79] [80]. Several ECs are poisonous and resistant to microbial development thus blocking biodegradation, in which situation a growth substrate is required to keep microbial development for biodegradation, a phenomenon recognized as cometabolism [12]. Biodegradation techniques have conventionally been utilized in wastewater treatment devices for eliminating ECs [81] [82]. They may be classified into aerobic and anaerobic techniques. Aerobic implementations involve activated sludge, MBR, and sequence batch reactor. Anaerobic techniques implicate anaerobic sludge reactors and anaerobic film reactors. The wastewater features have a fundamental contribution in choosing biological techniques [9] [83]. The wastewater treatment methods may be largely categorized as traditional processes and non-traditional processes, which are depicted in next sections [1] [66] [84].

The decomposition potential of ECs is a function of the chemical and biological persistence of ECs, their physicochemical characteristics, the technique applied and running parameters. For the highly polar substances (such as most pharmaceuticals and their corresponding metabolites), the most substantial removal mode is via the biological conversion or mineralization by microbes. The elimination yields greatly depend upon the treatment method, the working factors, and pointed pollutants [85]. Distinguishing decomposition products in environmental samples is hard work since not only are they found at so small concentrations but also they are existing in complex matrices that may interfere with detection [85] [86].

More details about progress and challenges in traditional treatment methods may be found in [1].

\section{Chemical Treatment Techniques}

Biological wastewater treatment techniques may be efficacious in eliminating several categories of ECs following the target chemicals, nature of wastewater, and running parameters [1] [87]. For instance, polar pharmaceuticals and beta-blockers depicted changing reduction performances in diverse biological techniques. Thus, chemical treatment processes have to be examined as replacements with the objective of discovering appropriate finishing technologies to more eliminate ECs [88] [89]. Such techniques are largely described as aqueous phase oxidation processes founded on the intermediary of highly reactive chemical species [90]. Oxidation reactions have mainly been employed to complete rather than substitute classical setups and to ameliorate removing ECs [91]. Chemicals like chlorine, hydrogen peroxide, ozone as well as the integration of these oxidants involving transition metals and metal oxides based catalysts in the so-called AOPs are needed for eliminating ECs from wastewater [92] [93]. Moreover, an energy source like UV-vis radiation, electric current, solar [94], gamma-radiation, and ultrasound are also utilized [95] [96]. In AOPs, oxidizing ECs is founded on generating free radicals, especially, hydroxyl radicals that ease the transformation of contaminants to less poisonous and more de- 
composable compounds [95] [97]. The final goal of chemical oxidation is the mineralization of contaminants, with their transformation to carbon dioxide, water, nitrogen, and other minerals. The rate constants for most reactions implying hydroxyl radicals in water are frequently in the order of $106-109 \mathrm{M}^{-1} \cdot \mathrm{s}^{-1}$ [1]. Chemical oxidation techniques may modify pharmaceuticals' polarity and the number of functional groups, which in turn influence their functionality in the organisms.

Progress and dares in classical oxidation methods are well explained by Ahmed et al. [1].

\section{Progress and Challenges in Hybrid Systems}

The classical wastewater treatment methods are not appropriate for eliminating efficiently several ECs [98]. A collection of hybrid treatment techniques is mentioned in the literature. Throughout the past decade, huge ameliorations have been reached in their usage in wastewater treatment, to avoid the liberation of ECs into the aquatic environment by effluent discharge [99]. Most of the hybrid systems are composed of biological-based treatment setup pursued by some physical or chemical treatment devices. Chemical oxidation founded treatment, as ozonation is the most largely employed method to merge with the biological processes. Several illustrations of these integrations comprise ozonation assisted by biological activated carbon, MBR-RO/UF/MF/ozonation, filtration and activated sludge pursued by UF [1]. MF and UF are ever more being viewed as replacements to granular media filtration [100].

\section{Future Tendencies}

Diverse biological and chemical-founded processes may efficiently eliminate distinct ECs; however, there are up to this time insufficiencies in the total elimination of ECs. Several additional research domains are proposed in Table 2 [1].

\section{Conclusions}

The main points drawn from this work may be given as:

1) Various biological techniques were observed to boost the reduction performance of diverse categories of ECs. As an illustration, the traditional activated sludge method has manifested better reduction performances for surfactants, EDCs, and PCPs than trickling filter and biofilm reactors, nitrification and denitrification techniques. Biological activated carbon method has been mentioned with ameliorated performances in the reduction of pesticides, analgesics, and antibiotics. MBR process has been detected to be hugely efficient in eliminating EDCs, PCPs, and beta-blockers than constructed wetlands. The new microalgae founded technique has the most elevated performance in eliminating diverse classes of ECs particularly pharmaceuticals and PCPs, even if no information was published on their elimination of beta-blockers, antibiotics, and surfactants [1] [110]. 
Table 2. Ten investigation areas suggested for the future [1].

\begin{tabular}{|c|c|}
\hline Research field & Description \\
\hline Research field \#1 & $\begin{array}{l}\text { There is a shortage of elaborated knowledge about the decomposition pathways implicated, the effect of running factors } \\
\text { on ECs elimination, reaction kinetics and reactor conception for excellent efficiency. }\end{array}$ \\
\hline Research field \#2 & Amalgamation of present treatment setups with nanoscale science and technology. \\
\hline Research field \#3 & $\begin{array}{l}\text { Dares related to wastewater sample preparations, analytical methods and validation protocols for the reliable analysis of } \\
\text { ECs in complicated environmental samples [101] [102]. }\end{array}$ \\
\hline Research field \#4 & $\begin{array}{l}\text { Reduction efficiency of various WWTP techniques at changing working situations has to be re-estimated employing } \\
\text { appropriate sampling procedures. }\end{array}$ \\
\hline Research field \#5 & $\begin{array}{l}\text { Employing solar irradiation has to be examined as a substitutional AOP technique for diminishing the prices of } \\
\text { huge-scale commercial implementations. }\end{array}$ \\
\hline Research field \#6 & $\begin{array}{l}\text { Composite techniques founded on merged chemical and biological treatment methods (like UV photolysis in the } \\
\text { existence of } \mathrm{H}_{2} \mathrm{O}_{2} \text { pursued by MBR or biological activated carbon, ozonation in the existence of } \mathrm{H}_{2} \mathrm{O}_{2} \text { pursued by MBR } \\
\text { or biological activated carbon, photo-Fenton pursued by MBR or biological activated carbon) have to be more tried. }\end{array}$ \\
\hline Research field \#7 & $\begin{array}{l}\text { Integrating physical methods (like gamma radiation and ultrasound with adsorption on activated carbon) may as well be } \\
\text { performed inside the actual wastewater treatment setups [103] [104]. }\end{array}$ \\
\hline Research field \#8 & $\begin{array}{l}\text { Ferrate method is a comparatively green technology and has to be more widely investigated for industrial-scale } \\
\text { utilizations [105] [106] [107] [108]. }\end{array}$ \\
\hline Research field \#9 & $\begin{array}{l}\text { Fresh comprehension in genetic engineering has to be inserted to choose and develop the most efficient microbes for } \\
\text { decomposing ECs, which will decrease hydraulic contact period and economize capital cost in reactor conception. }\end{array}$ \\
\hline Research field \#10 & $\begin{array}{l}\text { The hardiness and feasibility of full-scale chemical oxidation techniques require to be widely studied to guarantee ECs } \\
\text { elimination performances and reduce poisonous by-products [109]. }\end{array}$ \\
\hline
\end{tabular}

2) Chemical oxidation processes (like ozonation $/ \mathrm{H}_{2} \mathrm{O}_{2}, \mathrm{UV}$ photolysis/ $\mathrm{H}_{2} \mathrm{O}_{2}$, and photo-Fenton) have been observed to be the best techniques for reducing pesticides, beta-blockers, and pharmaceuticals. Ozonation and UV photocatalysis techniques are greatly efficacious in eliminating EDCs. The Fenton process has been illustrated to be the minimum efficient between all sorts of classical and AOPs treatment techniques. Reducing surfactants and PCPs via chemical techniques has not so far been well-tried [1].

3) Merged setups (like MBR pursued by RO, NF or UF) are better for eliminating EDCs and pharmaceuticals; however, they are less performant in reducing pesticides. Ozonation pursued by a biological activated carbon hybrid system has been found to be efficient in decreasing pesticides, beta-blockers, and pharmaceuticals. Ozonation pursued by ultrasound hybrid system may eliminate to $100 \%$ of some pharmaceuticals like salicylic acid, ibuprofen, naproxen, acetaminophen, cocaethylene, benzoylecgonine, enalapril, nor-benzoylecgonine, ketoprofen, atorvastatin, bezafibrate, clindamycin, sulfamethazine, and 4-aminoantipyrine. Additional hybrid systems founded on activated sludge pursued by UF or activated sludge pursued by gamma radiation are cost-effective for eliminating some EDCs, pesticides, and analgesic pharmaceuticals. Combined setups employing ultrafiltration, activated carbon pursued by the ultrasound process may be a better technology to deal with a large variety of ECs; however, they may not be cost-effective. 


\section{Conflicts of Interest}

The authors declare no conflicts of interest regarding the publication of this paper.

\section{References}

[1] Ahmed, M.B., Zhou, J.L., Ngo, H.H., Guo, W., Thomaidis, N.S. and Xu, J. (2017) Progress in the Biological and Chemical Treatment Technologies for Emerging Contaminant Removal from Wastewater: A Critical Review. Journal of Hazardous Materials, 323, 274-298. https://doi.org/10.1016/j.jhazmat.2016.04.045

[2] Grassi, M., Kaykioglu, G., Belgiorno, V. and Lofrano, G. (2012) Removal of Emerging Contaminants from Water and Wastewater by Adsorption Process. In: Lofrano, G., Ed., Emerging Compounds Removal from Wastewater, Springer, New York, 15-37. https://doi.org/10.1007/978-94-007-3916-1_2

[3] De la Cruz, N., Giménez, J., Esplugas, S., Grandjean, D., De Alencastro, L. and Pulgarin, C. (2012) Degradation of 32 Emergent Contaminants by UV and Neutral Photo-Fenton in Domestic Wastewater Effluent Previously Treated by Activated Sludge. Water Research, 46, 1947-1957. https://doi.org/10.1016/j.watres.2012.01.014

[4] Chen, K. and Zhou, J.L. (2014) Occurrence and Behavior of Antibiotics in Water and Sediments from the Huangpu River, Shanghai, China. Chemosphere, 95, 604-612. https://doi.org/10.1016/j.chemosphere.2013.09.119

[5] Ghernaout, D., Ghernaout, B., Boucherit, A., Naceur, M.W., Khelifa, A. and Kellil, A. (2009) Study on Mechanism of Electrocoagulation with Iron Electrodes in Idealised Conditions and Electrocoagulation of Humic Acids Solution in Batch Using Aluminium Electrodes. Desalination and Water Treatment, 8, 91-99.

https://doi.org/10.5004/dwt.2009.668

[6] Garcia-Rodríguez, A., Matamoros, V., Fontàs, C. and Salvadó, V. (2014) The Ability of Biologically Based Wastewater Treatment Systems to Remove Emerging Organic Contaminants-A Review. Environmental Science and Pollution Research, 21, 11708-11728. https://doi.org/10.1007/s11356-013-2448-5

[7] Dolar, D., Gros, M., Rodriguez-Mozaz, S., Moreno, J., Comas, J., Rodriguez-Roda, I. and Barceló, D. (2012) Removal of Emerging Contaminants from Municipal Wastewater with an Integrated Membrane System, MBR-RO. Journal of Hazardous Materials, 239, 64-69. https://doi.org/10.1016/j.jhazmat.2012.03.029

[8] Ahmed, M.B., Zhou, J.L., Ngo, H.H. and Guo, W. (2015) Adsorptive Removal of Antibiotics from Water and Wastewater: Progress and Challenges. Science of The Total Environment, 532, 112-126. https://doi.org/10.1016/j.scitotenv.2015.05.130

[9] Deegan, A., Shaik, B., Nolan, K., Urell, K., Oelgemöller, M., Tobin, J. and Morrissey, A. (2011) Treatment Options for Wastewater Effluents from Pharmaceutical Companies. International Journal of Environmental Science \& Technology, 8, 649-666. https://doi.org/10.1007/BF03326250

[10] Prieto-Rodriguez, L., Miralles-Cuevas, S., Oller, I., Agüera, A., Puma, G.L. and Malato, S. (2012) Treatment of Emerging Contaminants in Wastewater Treatment Plants (WWTP) Effluents by Solar Photocatalysis Using Low $\mathrm{TiO}_{2}$ Concentrations. Journal of Hazardous Materials, 211, 131-137. https://doi.org/10.1016/j.jhazmat.2011.09.008

[11] Klamerth, N., Malato, S., Agüera, A., Fernández-Alba, A. and Mailhot, G. (2012) Treatment of Municipal Wastewater Treatment Plant Effluents with Modified Photo-Fenton as a Tertiary Treatment for the Degradation of Micro Pollutants and 
Disinfection. Environmental Science \& Technology, 46, 2885-2892. https://doi.org/10.1021/es204112d

[12] Tran, N.H., Urase, T., Ngo, H.H., Hu, J. and Ong, S.L. (2013) Insight into Metabolic and Cometabolic Activities of Autotrophic and Heterotrophic Microorganisms in the Biodegradation of Emerging Trace Organic Contaminants. Bioresource Technology, 146, 721-731. https://doi.org/10.1016/j.biortech.2013.07.083

[13] Belhaj, D., Baccar, R., Jaabiri, I., Bouzid, J., Kallel, M., Ayadi, H. and Zhou, J.L. (2015) Fate of Selected Estrogenic Hormones in an Urban Sewage Treatment Plant in Tunisia (North Africa). Science of The Total Environment, 505, 154-160. https://doi.org/10.1016/j.scitotenv.2014.10.018

[14] Klamerth, N., Malato, S., Agüera, A. and Fernández-Alba, A. (2013) Photo-Fenton and Modified Photo-Fenton at Neutral $\mathrm{pH}$ for the Treatment of Emerging Contaminants in Wastewater Treatment Plant Effluents: A Comparison. Water Research, 47, 833-840. https://doi.org/10.1016/j.watres.2012.11.008

[15] Luo, Y., Guo, W., Ngo, H.H., Nghiem, L.D., Hai, F.I., Zhang, J., Liang, S. and Wang, X.C. (2014) A Review on the Occurrence of Micropollutants in the Aquatic Environment and Their Fate and Removal during Wastewater Treatment. Science of The Total Environment, 473, 619-641. https://doi.org/10.1016/j.scitotenv.2013.12.065

[16] Esplugas, S., Bila, D.M., Krause, L.G.T. and Dezotti, M. (2007) Ozonation and Advanced Oxidation Technologies to Remove Endocrine Disrupting Chemicals (EDCs) and Pharmaceuticals and Personal Care Products (PPCPs) in Water Effluents. Journal of Hazardous Materials, 149, 631-642. https://doi.org/10.1016/j.jhazmat.2007.07.073

[17] Rivera-Utrilla, J., Sánchez-Polo, M., Ferro-García, M.Á., Prados-Joya, G. and Campo-Pérez, R.O. (2013) Pharmaceuticals as Emerging Contaminants and Their Removal from Water: A Review. Chemosphere, 93, 1268-1287. https://doi.org/10.1016/j.chemosphere.2013.07.059

[18] Tijani, J.O., Fatoba, O.O. and Petrik, L.F. (2013) A Review of Pharmaceuticals and Endocrine-Disrupting Compounds: Sources, Effects, Removal, and Detections. Water, Air, \& Soil Pollution, 224, 1-29. https://doi.org/10.1007/s11270-013-1770-3

[19] Lister, A.L. and van Der Kraak, G.J. (2001) Endocrine Disruption: Why Is It So Complicated? Water Quality Research Journal, 36, 175-190.

https://doi.org/10.2166/wqri.2001.011

[20] Dunier, M. and Siwicki, A.K. (1993) Effects of Pesticides and Other Organic Pollutants in the Aquatic Environment on Immunity of Fish: A Review. Fish \& Shellfish Immunology, 3, 423-438. https://doi.org/10.1006/fsim.1993.1042

[21] Katakam, M., Bell, L.N. and Banga, A.K. (1995) Effect of Surfactants on the Physical Stability of Recombinant Human Growth Hormone. Journal of Pharmaceutical Sciences, 84, 713-716. https://doi.org/10.1002/jps.2600840609

[22] Zhang, Y. and Zhou, J.L. (2008) Occurrence and Removal of Endocrine Disrupting Chemicals in Wastewater. Chemosphere, 73, 848-853.

https://doi.org/10.1016/j.chemosphere.2008.06.001

[23] Grover, D.P., Zhou, J., Frickers, P. and Readman, J. (2011) Improved Removal of Estrogenic and Pharmaceutical Compounds in Sewage Effluent by Full-Scale Granular Activated Carbon: Impact on Receiving River Water. Journal of Hazardous Materials, 185, 1005-1011. https://doi.org/10.1016/j.jhazmat.2010.10.005

[24] Ghernaout, D., Moulay, S., Ait Messaoudene, N., Aichouni, M., Naceur, M.W. and Boucherit, A. (2014) Coagulation and Chlorination of NOM and Algae in Water 
Treatment: A Review. International Journal of Environmental Monitoring and Analysis, 2, 23-34. https://doi.org/10.11648/j.ijema.s.2014020601.14

[25] Ghernaout, D. (2019) Electrocoagulation Process for Microalgal Biotechnology-A Review. Applied Engineering, 3, 85-94.

[26] Ghernaout, D., Ghernaout, B., Saiba, A., Boucherit, A. and Kellil, A. (2009) Removal of Humic Acids by Continuous Electromagnetic Treatment Followed by Electrocoagulation in Batch Using Aluminium Electrodes. Desalination, 239, 295-308. https://doi.org/10.1016/j.desal.2008.04.001

[27] Ghernaout, D., Ghernaout, B. and Kellil, A. (2009) Natural Organic Matter Removal and Enhanced Coagulation as a Link between Coagulation and Electrocoagulation. Desalination and Water Treatment, 2, 203-222.

https://doi.org/10.5004/dwt.2009.116

[28] Ghernaout, D. (2013) Advanced Oxidation Phenomena in Electrocoagulation Process: A Myth or a Reality? Desalination and Water Treatment, 51, 7536-7554. https://doi.org/10.1080/19443994.2013.792520

[29] Saiba, A., Kourdali, S., Ghernaout, B. and Ghernaout, D. (2010) In Desalination, from 1987 to 2009, the Birth of a New Seawater Pretreatment Process: Electrocoagulation-An Overview. Desalination and Water Treatment, 16, 201-217. https://doi.org/10.5004/dwt.2010.1094

[30] Ghernaout, D. and Naceur, M.W. (2011) Ferrate(VI): In Situ Generation and Water Treatment-A Review. Desalination and Water Treatment, 30, 319-332. https://doi.org/10.5004/dwt.2011.2217

[31] Ghernaout, D. and Elboughdiri, N. (2019) Mechanistic Insight into Disinfection Using Ferrate(VI). Open Access Library Journal, 6, e5946.

[32] Ghernaout, D. and Elboughdiri, N. (2019) Water Disinfection: Ferrate(VI) as the Greenest Chemical-A Review. Applied Engineering, 3, 171-180.

[33] Ghernaout, D. (2017) Microorganisms' Electrochemical Disinfection Phenomena. EC Microbiology, 9, 160-169.

[34] Ghernaout, D., Touahmia, M. and Aichouni, M. (2019) Disinfecting Water: Electrocoagulation as an Efficient Process. Applied Engineering, 3, 1-12.

[35] Ghernaout, D., Aichouni, M. and Touahmia, M. (2019) Mechanistic Insight into Disinfection by Electrocoagulation-A Review. Desalination and Water Treatment, 141, 68-81. https://doi.org/10.5004/dwt.2019.23457

[36] Ghernaout, D. (2019) Virus Removal by Electrocoagulation and Electrooxidation: New Findings and Future Trends. Journal of Environmental Science and Allied Research, 2019, 85-90. https://doi.org/10.29199/2637-7063/ESAR-202024

[37] Ghernaout, D., Benblidia, C. and Khemici, F. (2015) Microalgae Removal from Ghrib Dam (Ain Defla, Algeria) Water by Electroflotation Using Stainless Steel Electrodes. Desalination and Water Treatment, 54, 3328-3337. https://doi.org/10.1080/19443994.2014.907749

[38] Ghernaout, B., Ghernaout, D. and Saiba, A. (2010) Algae and Cyanotoxins Removal by Coagulation/Flocculation: A Review. Desalination and Water Treatment, 20, 133-143. https://doi.org/10.5004/dwt.2010.1202

[39] Ghernaout, D. and Ghernaout, B. (2012) On the Concept of the Future Drinking Water Treatment Plant: Algae Harvesting from the Algal Biomass for Biodiesel Production-A Review. Desalination and Water Treatment, 49, 1-18. https://doi.org/10.1080/19443994.2012.708191

[40] Ghernaout, D. (2017) Water Treatment Chlorination: An Updated Mechanistic In- 
sight Review. Chemistry Research Journal, 2, 125-138.

[41] Ghernaout, D. (2017) The Holy Koran Revelation: Iron Is a "Sent Down" Metal. American Journal of Environmental Protection, 6, 101-104. https://doi.org/10.11648/j.ajep.20170604.14

[42] Ghernaout, D. (2018) Magnetic Field Generation in the Water Treatment Perspectives: An Overview. International Journal of Advanced and Applied Sciences, 5, 193-203. https://doi.org/10.21833/ijaas.2018.01.025

[43] Ghernaout, D. (2019) Aeration Process for Removing Radon from Drinking Water-A Review. Applied Engineering, 3, 32-45.

[44] Ghernaout, D. and El-Wakil, A. (2017) Requiring Reverse Osmosis Membranes Modifications-An Overview. American Journal of Chemical Engineering, 5, 81-88. https://doi.org/10.11648/j.ajche.20170504.15

[45] Ghernaout, D., El-Wakil, A., Alghamdi, A., Elboughdiri, N. and Mahjoubi, A. (2018) Membrane Post-Synthesis Modifications and How It Came about. International Journal of Advanced and Applied Sciences, 5, 60-64. ttps://doi.org/10.21833/ijaas.2018.02.010

[46] Ghernaout, D., Naceur, M.W. and Ghernaout, B. (2011) A Review of Electrocoagulation as a Promising Coagulation Process for Improved Organic and Inorganic Matters Removal by Electrophoresis and Electroflotation. Desalination and Water Treatment, 28, 287-320. https://doi.org/10.5004/dwt.2011.1493

[47] Ghernaout, D., Irki, S. and Boucherit, A. (2014) Removal of $\mathrm{Cu}^{2+}$ and $\mathrm{Cd}^{2+}$, and Humic Acid and Phenol by Electrocoagulation Using Iron Electrodes. Desalination and Water Treatment, 52, 3256-3270. https://doi.org/10.1080/19443994.2013.852484

[48] Ghernaout, D. (2014) The Hydrophilic/Hydrophobic Ratio vs. Dissolved Organics Removal by Coagulation-A Review. Journal of King Saud University-Science, 26, 169-180. https://doi.org/10.1016/j.jksus.2013.09.005

[49] Ghernaout, D., Al-Ghonamy, A.I., Naceur, M.W., Ait Messaoudene, N. and Aichouni, M. (2014) Influence of Operating Parameters on Electrocoagulation of C.I. Disperse Yellow 3. Journal of Electrochemical Science and Engineering, 4, 271-283. https://doi.org/10.5599/jese.2014.0065

[50] Ghernaout, D., Al-Ghonamy, A.I., Irki, S., Grini, A., Naceur, M.W., Ait Messaoudene, N. and Aichouni, M. (2014) Decolourization of Bromophenol Blue by Electrocoagulation Process. Trends in Chemical Engineering, 15, 29-39.

[51] Ghernaout, D., Al-Ghonamy, A.I., Boucherit, A., Ghernaout, B., Naceur, M.W., Ait Messaoudene, N., Aichouni, M., Mahjoubi, A.A. and Elboughdiri, N.A. (2015) Brownian Motion and Coagulation Process. American Journal of Environmental Protection, 4, 1-15.

[52] Ghernaout, D., Al-Ghonamy, A.I., Naceur, M.W., Boucherit, A., Messaoudene, N.A., Aichouni, M., Mahjoubi, A.A. and Elboughdiri, N.A. (2015) Controlling Coagulation Process: From Zeta Potential to Streaming Potential. American Journal of Environmental Protection, 4, 16-27. https://doi.org/10.11648/j.ajeps.s.2015040501.12

[53] Ghernaout, D., Al-Ghonamy, A.I., Ait Messaoudene, N., Aichouni, M., Naceur, M.W., Benchelighem, F.Z. and Boucherit, A. (2015) Electrocoagulation of Direct Brown 2 (DB) and BF Cibacete Blue (CB) Using Aluminum Electrodes. Separation Science and Technology, 50, 1413-1420. https://doi.org/10.1080/01496395.2014.982763 
[54] Irki, S., Ghernaout, D. and Naceur, M.W. (2017) Decolourization of Methyl Orange (MO) by Electrocoagulation (EC) Using Iron Electrodes under a Magnetic Field (MF). Desalination and Water Treatment, 79, 368-377. https://doi.org/10.5004/dwt.2017.20797

[55] Ghernaout, D. (2017) Entropy in the Brownian Motion (BM) and Coagulation Background. Colloid and Surface Science, 2, 143-161.

[56] Ghernaout, D. (2018) Electrocoagulation Process: Achievements and Green Perspectives. Colloid and Surface Science, 3, 1-5. https://doi.org/10.11648/j.css.20180301.11

[57] Ghernaout, D., Simoussa, A., Alghamdi, A., Ghernaout, B., Elboughdiri, N., Mahjoubi, A., Aichouni, M. and El-Wakil, A.E.A. (2018) Combining Lime Softening with Alum Coagulation for Hard Ghrib Dam Water Conventional Treatment. International Journal of Advanced and Applied Sciences, 5, 61-70. https://doi.org/10.21833/ijaas.2018.05.008

[58] Djezzar, S., Ghernaout, D., Cherifi, H., Alghamdi, A., Ghernaout, B. and Aichouni, M. (2018) Conventional, Enhanced, and Alkaline Coagulation for Hard Ghrib Dam (Algeria) Water. World Journal of Applied Chemistry, 3, 41-55. https://doi.org/10.11648/j.wjac.20180302.12

[59] Irki, S., Ghernaout, D., Naceur, M.W., Alghamdi, A. and Aichouni, M. (2018) Decolorization of Methyl Orange (MO) by Electrocoagulation (EC) Using Iron Electrodes under a Magnetic Field (MF). II. Effect of Connection Mode. World Journal of Applied Chemistry, 3, 56-64. https://doi.org/10.11648/j.wjac.20180302.13

[60] Irki, S., Ghernaout, D., Naceur, M.W., Alghamdi, A. and Aichouni, M. (2018) Decolorizing Methyl Orange by Fe-Electrocoagulation Process-A Mechanistic Insight. International Journal of Environmental Chemistry, 2, 18-28. https://doi.org/10.11648/j.ijec.20180201.14

[61] Ghernaout, D., Alghamdi, A. and Ghernaout, B. (2019) Electrocoagulation Process: A Mechanistic Review at the Dawn of Its Modeling. Journal of Environmental Science and Allied Research, 2, 51-67. https://doi.org/10.29199/2637-7063/ESAR-201019

[62] Ghernaout, D. (2018) Disinfection and DBPs Removal in Drinking Water Treatment: A Perspective for a Green Technology. International Journal of Advanced and Applied Sciences, 5, 108-117. https://doi.org/10.21833/ijaas.2018.02.018

[63] Ghernaout, D. and Ghernaout, B. (2010) From Chemical Disinfection to Electrodisinfection: The Obligatory Itinerary? Desalination and Water Treatment, 16, 156-175. https://doi.org/10.5004/dwt.2010.1085

[64] Boucherit, A., Moulay, S., Ghernaout, D., Al-Ghonamy, A.I., Ghernaout, B., Naceur, M.W., Ait Messaoudene, N., Aichouni, M., Mahjoubi, A.A. and Elboughdiri, N.A. (2015) New Trends in Disinfection by-Products Formation upon Water Treatment. Journal of Research \& Developments in Chemistry, 2015, Article ID: 628833.

[65] Ait Messaoudene, N., Naceur, M.W., Ghernaout, D., Alghamdi, A. and Aichouni, M. (2018) On the Validation Perspectives of the Proposed Novel Dimensionless Fouling Index. International Journal of Advanced and Applied Sciences, 5, 116-122.

[66] Ghernaout, D., Alshammari, Y., Alghamdi, A., Aichouni, M., Touahmia, M. and Ait Messaoudene, N. (2018) Water Reuse: Extenuating Membrane Fouling in Membrane Processes. International Journal of Environmental Chemistry, 2, 1-12. https://doi.org/10.11648/j.ajche.20180602.12

[67] Stackelberg, P.E., Gibs, J., Furlong, E.T., Meyer, M.T., Zaugg, S.D. and Lippincott, R.L. (2007) Efficiency of Conventional Drinking-Water-Treatment Processes in 
Removal of Pharmaceuticals and Other Organic Compounds. Science of The Total Environment, 377, 255-272. https://doi.org/10.1016/j.scitotenv.2007.01.095

[68] Snyder, S., Lei, H., Wert, E., Westerhoff, P. and Yoon, Y. (2008) Removal of EDCs and Pharmaceuticals in Drinking Water. Water Environment Research Foundation.

[69] Westerhoff, P., Yoon, Y., Snyder, S. and Wert, E. (2005) Fate of Endocrine-Disruptor Pharmaceutical, and Personal Care Product Chemicals during Simulated Drinking Water Treatment Processes. Environmental Science \& Technology, 39, 6649-6663. https://doi.org/10.1021/es0484799

[70] Ghernaout, D. (2017) Reverse Osmosis Process Membranes Modeling-A Historical Overview. Journal of Civil, Construction and Environmental Engineering, 2, 112-122.

[71] Ghernaout, D. (2019) Brine Recycling: Towards Membrane Processes as the Best Available Technology. Applied Engineering, 3, 71-84.

[72] Ghernaout, D. (2019) Electrocoagulation and Electrooxidation for Disinfecting Water: New Breakthroughs and Implied Mechanisms. Applied Engineering, 3, 125-133.

[73] Ghernaout, D. and Elboughdiri, N. (2019) Electrocoagulation Process Intensification for Disinfecting Water-A Review. Applied Engineering, 3, 140-147.

[74] Ghernaout, D. and Elboughdiri, N. (2019) Iron Electrocoagulation Process for Disinfecting Water-A Review. Applied Engineering, 3, 154-158.

[75] Ghernaout, D. (2019) Disinfection via Electrocoagulation Process: Implied Mechanisms and Future Tendencies. EC Microbiology, 15, 79-90.

[76] Ghernaout, D., Badis, A., Braikia, G., Matâam, N., Fekhar, M., Ghernaout, B. and Boucherit, A. (2017) Enhanced Coagulation for Algae Removal in a Typical Algeria Water Treatment Plant. Environmental Engineering and Management Journal, 16, 2303-2315. https://doi.org/10.30638/eemj.2017.238

[77] Kellali, Y. and Ghernaout, D. (2019) Physicochemical and Algal Study of Three Dams (Algeria) and Removal of Microalgae by Enhanced Coagulation. Applied Engineering, 3, 56-64.

[78] Ghernaout, D., Alghamdi, A. and Ghernaout, B. (2019) Microorganisms' Killing: Chemical Disinfection vs. Electrodisinfection. Applied Engineering, 3, 13-19.

[79] Ghernaout, D. (2019) Greening Electrocoagulation Process for Disinfecting Water. Applied Engineering, 3, 27-31.

[80] Ghernaout, D., Badis, A., Ghernaout, B. and Kellil, A. (2008) Application of Electrocoagulation in Escherichia coli Culture and Two Surface Waters. Desalination, 219, 118-125. https://doi.org/10.1016/j.desal.2007.05.010

[81] Ghernaout, D., Elboughdiri, N. and Ghareba, S. (2019) Drinking Water Reuse: One-Step Closer to Overpassing the "Yuck Factor". Open Access Library Journal, 6, e5895.

[82] Ghernaout, D., Elboughdiri, N. and Al Arni, S. (2019) Water Reuse (WR): Dares, Restrictions, and Trends. Applied Engineering, 3, 159-170.

[83] Raj, D.S.S. and Anjaneyulu, Y. (2005) Evaluation of Biokinetic Parameters for Pharmaceutical Wastewaters Using Aerobic Oxidation Integrated with Chemical Treatment. Process Biochemistry, 40, 165-175. https://doi.org/10.1016/j.procbio.2003.11.056

[84] Ghernaout, D. (2017) Water Reuse (WR): The Ultimate and Vital Solution for Water Supply Issues. International Journal of Sustainable Development Research, 3, 36-46. https://doi.org/10.11648/j.ijsdr.20170304.12 
[85] Barceló, D. and Petrovic, M. (2008) Conclusions and Future Research Needs. In: Emerging Contaminants from Industrial and Municipal Waste, Springer, New York, 265-274. https://doi.org/10.1007/978-3-540-79210-9_9

[86] Zhou, J.L., Zhang, Z., Banks, E., Grover, D. and Jiang, J.Q. (2009) Pharmaceutical Residues in Wastewater Treatment Works Effluents and Their Impact on Receiving River Water. Journal of Hazardous Materials, 166, 655-661. https://doi.org/10.1016/j.jhazmat.2008.11.070

[87] Ghernaout, D., Alshammari, Y. and Alghamdi, A. (2018) Improving Energetically Operational Procedures in Wastewater Treatment Plants. International Journal of Advanced and Applied Sciences, 5, 64-72. https://doi.org/10.21833/ijaas.2018.09.010

[88] Ghernaout, D., Naceur, M.W. and Aouabed, A. (2011) On the Dependence of Chlorine by-Products Generated Species Formation of the Electrode Material and Applied Charge during Electrochemical Water Treatment. Desalination, 270, 9-22. https://doi.org/10.1016/j.desal.2011.01.010

[89] Ghernaout, D., Ghernaout, B. and Naceur, M.W. (2011) Embodying the Chemical Water Treatment in the Green Chemistry-A Review. Desalination, 271, 1-10. https://doi.org/10.1016/j.desal.2011.01.032

[90] Comninellis, C., Kapalka, A., Malato, S., Parsons, S.A., Poulios, I. and Mantzavinos, D. (2008) Advanced Oxidation Processes for Water Treatment: Advances and Trends for R \& D. Journal of Chemical Technology \& Biotechnology, 83, 769-776. https://doi.org/10.1002/jctb.1873

[91] Balcioğlu, I.A. and Ötker, M. (2003) Treatment of Pharmaceutical Wastewater Containing Antibiotics by $\mathrm{O}_{3}$ and $\mathrm{O}_{3} / \mathrm{H}_{2} \mathrm{O}_{2}$ Processes. Chemosphere, 50, 85-95. https://doi.org/10.1016/S0045-6535(02)00534-9

[92] Ghernaout, D., Alghamdi, A., Aichouni, M. and Touahmia, M. (2018) The Lethal Water Tri-Therapy: Chlorine, Alum, and Polyelectrolyte. World Journal of Applied Chemistry, 3, 65-71. https://doi.org/10.11648/j.wjac.20180302.14

[93] Alshammari, Y., Ghernaout, D., Aichouni, M. and Touahmia, M. (2018) Improving Operational Procedures in Riyadh's (Saudi Arabia) Water Treatment Plants Using Quality Tools. Applied Engineering, 2, 60-71.

[94] Ghernaout, D., Alghamdi, A., Touahmia, M., Aichouni, M. and Ait Messaoudene, N. (2018) Nanotechnology Phenomena in the Light of the Solar Energy. Journal of Energy, Environmental \& Chemical Engineering, 3, 1-8. https://doi.org/10.11648/j.jeece.20180301.11

[95] Ikehata, K., Gamal El-Din, M. and Snyder, S.A. (2008) Ozonation and Advanced Oxidation Treatment of Emerging Organic Pollutants in Water and Wastewater. Ozone: Science \& Engineering, 30, 21-26. https://doi.org/10.1080/01919510701728970

[96] Ghernaout, D. (2019) Greening Cold Fusion as an Energy Source for Water Treatment Distillation-A Perspective. American Journal of Quantum Chemistry and Molecular Spectroscopy, 3, 1-5.

[97] Ikehata, K., Jodeiri Naghashkar, N. and Gamal El-Din, M. (2006) Degradation of Aqueous Pharmaceuticals by Ozonation and Advanced Oxidation Processes: A Review. Ozone: Science \& Engineering, 28, 353-414. https://doi.org/10.1080/01919510600985937

[98] Al Arni, S., Amous, J. and Ghernaout, D. (2019) On the Perspective of Applying of a New Method for Wastewater Treatment Technology: Modification of the Third Traditional Stage with Two Units, One by Cultivating Microalgae and Another by 
Solar Vaporization. International Journal of Environmental Science and Technology, 16, Article ID: 555934. https://doi.org/10.19080/IJESNR.2019.16.555934

[99] Ghernaout, D. (2019) Reviviscence of Biological Wastewater Treatment-A Review. Applied Engineering, 3, 46-55.

[100] Stoquart, C., Servais, P., Bérubé, P.R. and Barbeau, B. (2012) Hybrid Membrane Processes Using Activated Carbon Treatment for Drinking Water: A Review. Journal of Membrane Science, 411-412, 1-12. https://doi.org/10.1016/j.memsci.2012.04.012

[101] Ghernaout, D., Aichouni, M. and Alghamdi, A. (2018) Overlapping ISO/IEC 17025:2017 into Big Data: A Review and Perspectives. International Journal of Science and Qualitative Analysis, 4, 83-92.

[102] Ghernaout, D., Aichouni, M., Alghamdi, A. and Ait Messaoudene, N. (2018) Big Data: Myths, Realities and Perspectives-A Remote Look. American Journal of Information Science and Technology, 2, 1-8. https://doi.org/10.11648/j.ajist.20180201.11

[103] Ghernaout, D. (2018) Increasing Trends towards Drinking Water Reclamation from Treated Wastewater. World Journal of Applied Chemistry, 3, 1-9. https://doi.org/10.11648/j.wjac.20180301.11

[104] Ghernaout, D. (2013) The Best Available Technology of Water/Wastewater Treatment and Seawater Desalination: Simulation of the Open Sky Seawater Distillation. Green and Sustainable Chemistry, 3, 68-88. https://doi.org/10.4236/gsc.2013.32012

[105] Belhout, D., Ghernaout, D., Djezzar-Douakh, S. and Kellil, A. (2010) Electrocoagulation of a Raw Water of Ghrib Dam (Algeria) in Batch Using Iron Electrodes. Desalination and Water Treatment, 16, 1-9. https://doi.org/10.5004/dwt.2010.1081

[106] Ghernaout, D., Mariche, A., Ghernaout, B. and Kellil, A. (2010) Electromagnetic Treatment-Bi-Electrocoagulation of Humic Acid in Continuous Mode Using Response Surface Method for Its Optimization and Application on Two Surface Waters. Desalination and Water Treatment, 22, 311-329. https://doi.org/10.5004/dwt.2010.1120

[107] Ghernaout, D. and Ghernaout, B. (2011) On the Controversial Effect of Sodium Sulphate as Supporting Electrolyte on Electrocoagulation Process: A Review. Desalination and Water Treatment, 27, 243-254. https://doi.org/10.5004/dwt.2011.1983

[108] Ghernaout, D., Ghernaout, B. and Boucherit, A. (2008) Effect of pH on Electrocoagulation of Bentonite Suspensions in Batch Using Iron Electrodes. Journal of Dispersion Science and Technology, 29, 1272-1275. https://doi.org/10.1080/01932690701857483

[109] Ghernaout, D. (2017) Environmental Principles in the Holy Koran and the Sayings of the Prophet Muhammad. American Journal of Environmental Protection, 6, 75-79. https://doi.org/10.11648/j.ajep.20170603.13

[110] Ghernaout, D., Aichouni, M. and Alghamdi, A. (2018) Applying Big Data (BD) in Water Treatment Industry: A New Era of Advance. International Journal of Advanced and Applied Sciences, 5, 89-97. https://doi.org/10.21833/ijaas.2018.03.013 


\section{Abbreviations}

$\begin{array}{ll}\text { AOPs } & \text { Advanced oxidation processes } \\ \text { ECs } & \text { Emerging contaminants } \\ \text { EDCs } & \text { Endocrine disruption chemicals } \\ \text { MBR } & \text { Membrane bioreactor } \\ \text { MF } & \text { Microfiltration } \\ \text { NF } & \text { Nanofiltration } \\ \text { PCPs } & \text { Personal care products } \\ \text { RO } & \text { Reverse osmosis } \\ \text { UF } & \text { Ultrafiltration } \\ \text { WWTP } & \text { Wastewater treatment plants }\end{array}$

